\author{
ACTA MYCOLOGICA \\ Vol. 48 (1): 5-11 \\ 2013
}

DOI: $10.5586 / \mathrm{am} .2013 .001$

\title{
Lawrynomyces, a new genus of corticioid fungi in the Hymenochaetales
}

\author{
DARIUSZ KARASIŃSKI
}

\begin{abstract}
Department of Mycology, W. Szafer Institute of Botany Polish Academy of Sciences Lubicz 46, PL-31-512 Kraków, d.karasinski@botany.pl
\end{abstract}

Karasiński D.: Lawrynomyces, a new genus of corticioid fungi in the Hymenochaetales. Acta Mycol. 48 (1): 5-11, 2013.

The new genus Lawrynomyces is proposed to accommodate Hyphoderma capitatum, a predominantly European species growing on decayed coniferous wood. The genus belongs to the Rickenella-clade in the order Hymenochaetales, and it includes species characterized by resupinate basidiomes, monomitic hyphal system with simple septate hyphae, presence of cystidia and hyphidia, suburniform to subcylindrical, pedunculate basidia, and subglobose to broadly ellipsoid basidiospores with slightly thickened walls not staining in Melzer's reagent or Cotton Blue. Published molecular data support the recognition of a distinct genus for Hyphoderma capitatum.

Key words: taxonomy, new genus, Hyphoderma

\section{INTRODUCTION}

Hyphoderma capitatum J. Erikss. \& Å. Strid was described from a specimen collected by Kurt Hjortstam in Alingsås, Sweden (Eriksson, Ryvarden 1975). Among the members of the genus Hyphoderma Wallr., it was considered to be a discordant taxon due to its simple septate hyphae and slightly thickened wall of the basidiospores. Recent phylogenetic studies revealed that Hyphoderma is polyphyletic and that most species cluster in two distinct, monophyletic clades (Larsson et al. 2004, 2006; Larsson 2007a, b). The generic type Hyphoderma setigerum (Fr.) Donk and related species were placed in the "phlebioid clade" (Meruliaceae, Polyporales). This Hyphoderma s.str. lineage is differentiated from other genera of the "phlebioid clade" by presence of suburniform basidia, tubular cystidia and cylindrical or elliptical spores (Larsson 2007a). The second lineage is in the Rickenella-clade of the Hymenochaetales. The members of this lineage produce clavate basidia and often unique cells called echinocysts and stephanocysts, which have a nutritional function (Hallenberg 1990) and capture and infect nematodes (Tzean, Liou 1993). To accommodate the species from this lineage, Larsson (2007a) reinstated the 
genus Peniophorella P. Karst., typified by P. pubera (Fr.) P. Karst. Systematic position of some species from both lineages were independently (intentionally or not) confirmed in other molecular studies (Miettinen, Larsson 2011; Miettinen, Rajchenberg 2012; Nakasone, Burdsall 2012; Tellería et al. 2012). However, some species of Hyphoderma, for example H. argillaceum (Bres.) Donk, H. capitatum, H. orphanellum (Bourdot \& Galzin) Donk and H. sibiricum (Parmasto) J. Erikss. \& A. Strid, were not included in Hyphoderma or Peniophorella in molecular phylogenetic studies.

In all published phylogenies, Hyphoderma capitatum was recognized as a member of the Rickenella-clade in the Hymenochaetales and clustered in a clade separate from species of Peniophorella. Morphologically, H. capitatum differs from Peniophorella species in having hyphae without clamps, suburniform-pedunculate basidia, basidiospores with slightly thickened walls, and lacking echinocysts and stephanocysts. Morphologic and molecular phylogenetic data suggest that Hyphoderma capitatum should be accommodated in a new genus that is described and illustrated here.

\section{MATERIALS AND METHODS}

Examined specimens were collected from the Kaszubski Landscape Park, northern Poland, in 2007-2008. Laboratory methods and abbreviations follow Karasiński (2010). Specimens are deposited in author's reference fungarium (Herb. D.K.) and duplicates are in KRAM.

\section{TAXONOMY}

Lawrynomyces Karasiński, gen. nov.

MycoBank MB 803871

Etymology: The genus is named in honor of Polish mycologist, Professor Maria Ławrynowicz.

Basidiomata resupinate, effused, adnate, thin. Hymenophore even, margin indeterminate, without rhizomorphs. Hyphal system monomitic. Hyphae with simple septa, thin to thick-walled, hyaline. Cystidia present. Hyphidia sometimes present. Basidia suburniform to subcylindrical and constricted, more or less pedunculate, basally without clamps, with (2-)4 prominent sterigmata. Basidiospores relatively large, broadly ellipsoid to subglobose, with slightly thickened walls and distinct apiculus, smooth, inamyloid, indextrinoid, acyanophilous.

Generic type: Hyphoderma capitatum J. Erikss. \& A. Strid.

Lawrynomyces capitatus (J. Erikss. \& Å. Strid) Karasiński, comb. nov.

Figs 1-3

MycoBank MB 803872

Basionym: Hyphoderma capitatum J. Erikss. \& Å. Strid, in Eriksson \& Ryvarden, Cortic. N. Eur., Coronicium-Hyphoderma 3: 461 (1975). 


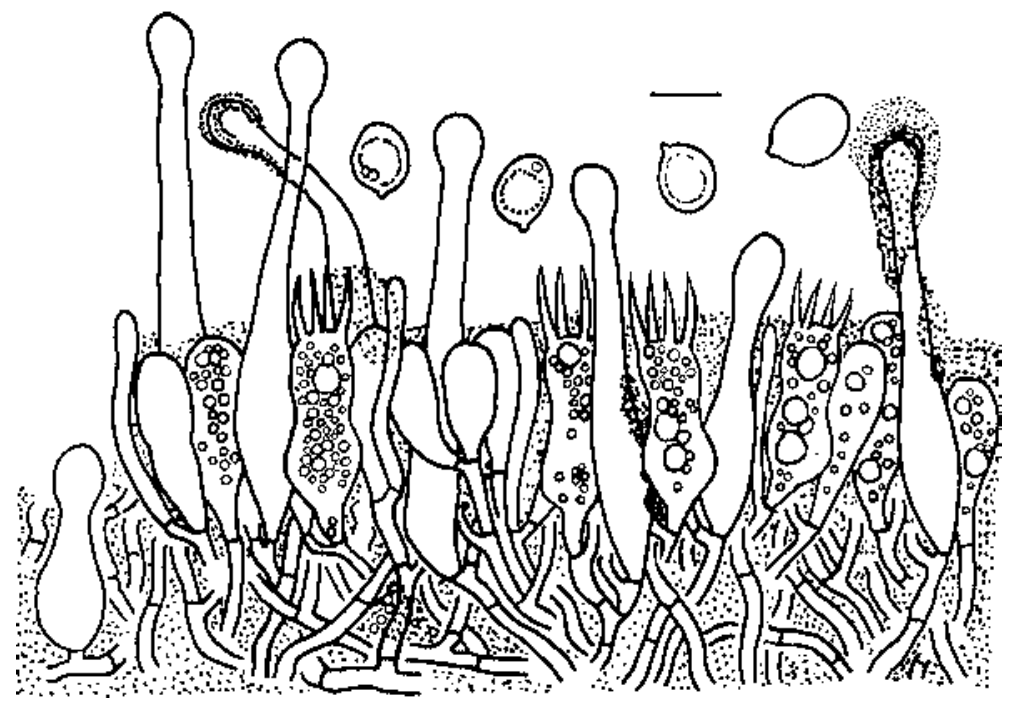

Fig. 1. Lawrynomyces capitatus - section through basidiomata. Line drawing from coll. Karasiński 970 (KRAM F-56623). Scale bar $=10 \mu \mathrm{m}$.

Basidiome resupinate, closely adnate, very thin, $60-150 \mu \mathrm{m}$ thick (excluding projecting cystidia), forming linear or irregular patches, becoming confluent with age, up to $20 \mathrm{~cm}$ in the longest dimension, soft, membranaceous, initially white, then grayish-white to grayish-cream, finally gray with brownish tint, dirty ochraceousgray when dry. Hymenophore smooth, discontinuous as seen by stereomicroscope, densely reticulate, pilose from projecting cystidia; margin indeterminate, sometimes abrupt, somewhat pruinose or minutely fimbriate to loosely reticulate in some parts. Odor or taste not known. Hyphal system monomitic, all hyphae with simple septa. Subiculum absent or in well developed basidiomes as a very thin layer of basal hyphae, 2-4.5 um wide, parallel to substrate, slightly thick-walled, hyaline, smooth, branching at right-angles; subhymenium 20-50(-70) $\mu \mathrm{m}$ thick, consisting vertically and loosely arranged hyphae, $2-4 \mu \mathrm{m}$ wide, sparsely branched, somewhat sinuous, thin-walled or up to $0.2 \mu \mathrm{m}$ thick, hyaline, without encrustation, but in mature specimens covered (in $\mathrm{KOH}$ ) with yellowish to brownish gray resinous matter; hymenial layer composed of cystidia, basidioles, basidia and hyphidia. Cystidia 55-105 $\mu \mathrm{m}$ long, with swollen base, 7-12(-16) $\mu \mathrm{m}$, tapering towards the apex and usually capitate, apical bulb 7-9.5(-11) $\mu \mathrm{m}$ in diameter, projecting up to $60 \mu \mathrm{m}$ above basidia, thin-walled or with slightly thickened walls except at apex, empty, not encrusted, apical bulb enclosed by hyaline or yellow matter observed in Melzer's reagent or Cotton Blue but dissolving in $\mathrm{KOH}$ and other media; in some well developed specimens, short capitate cystidia produced from basal hyphae, approximately $30 \mu \mathrm{m}$ long. Basidia $32-48 \times 10-13 \mu \mathrm{m}$, suburniform to subcylindrical and constricted, more or less distinctly pedunculate, with oily granules in the protoplasm, without basal clamp, with 4 prominent sterigmata ca. $10 \times 2.5 \mu \mathrm{m}$, 2 -sterigmate basidia not observed in studied material. Hyphidia scarce, enclosed or only slightly projecting, obtuse at apex, 3-5 $\mu \mathrm{m}$ wide, hyaline, thin-walled, smooth. 


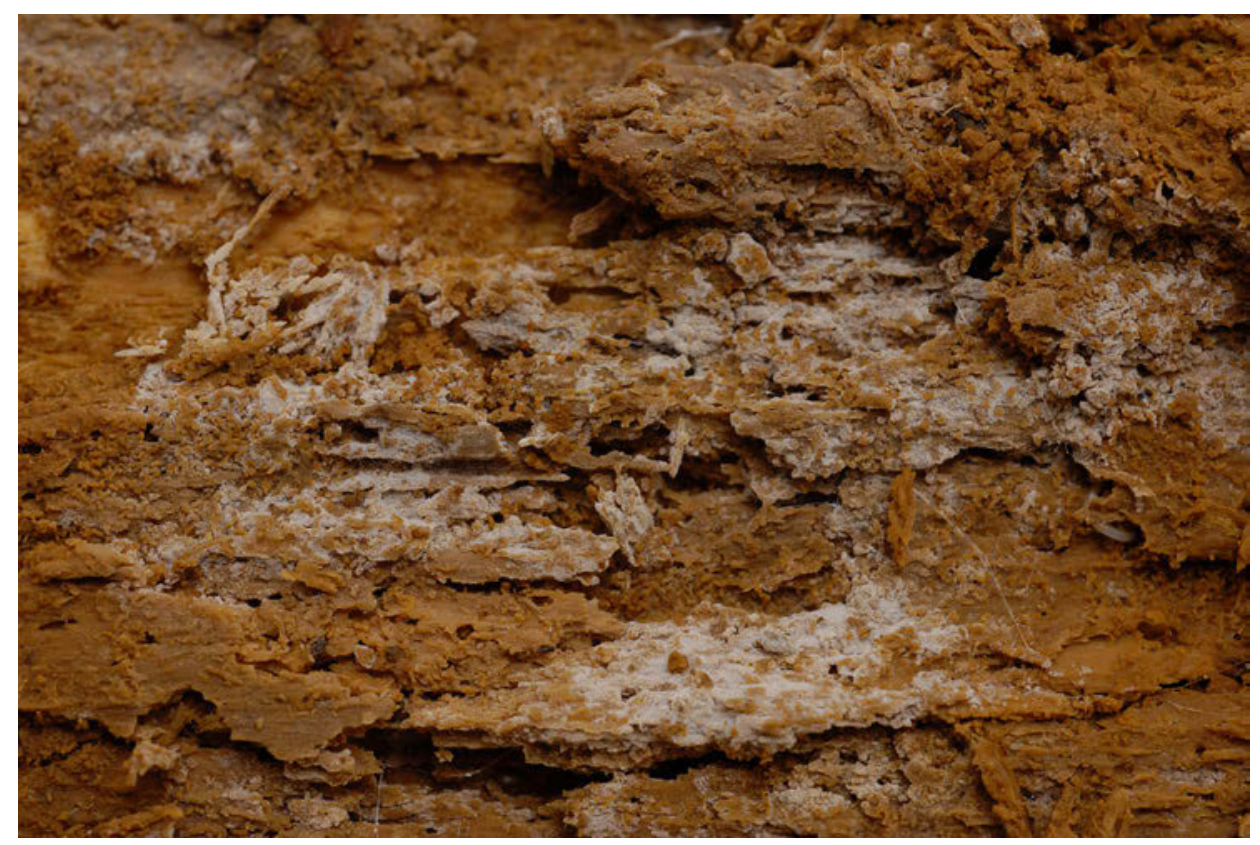

Fig. 2. Lawrynomyces capitatus - young basidiomata on very rotted wood of Pinus sylvestris stump. Coll. Karasiński 2744 (Herb. D.K.).

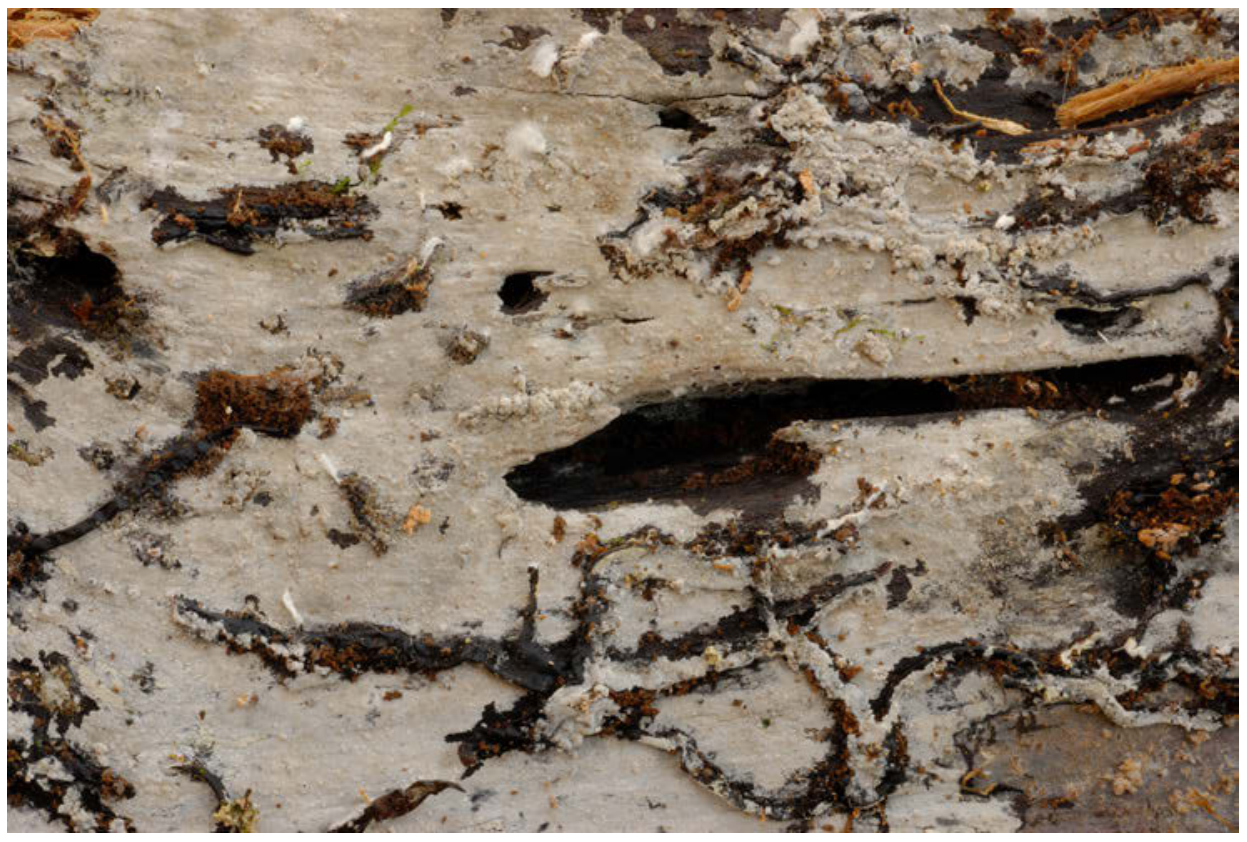

Fig. 3. Lawrynomyces capitatus - mature and well developed basidiomata on much rotted wood of Picea abies stump. Coll. Karasiński 970 (KRAM F-56623?). 
Basidiospores (8.8-)9-13.2(-14) $\times(7-) 8.5-11(-11.5) \mu \mathrm{m}(\mathrm{Lm}=11.2 \mu \mathrm{m}, \mathrm{Wm}=9.3$ $\mu \mathrm{m}, \mathrm{Q}=1.1-1.4 \mu \mathrm{m}, \mathrm{Qm}=1.2 \mu \mathrm{m}, \mathrm{n}=120 / 4)$, subglobose to broadly ellipsoid, hyaline, containing one large or many small oil drops, smooth, with thickened walls and prominent apiculus, inamyloid, acyanophilous.

Specimens eXamined: Poland. Pojezierze Kaszubskie lakeland: Kaszubski Landscape Park, Lasy Mirachowskie forests, ca. $1.5 \mathrm{~km} \mathrm{~N}$ of Miechucino, managed mixed forest, on very rotted wood of Picea abies (L.) H. Karst. stump, 26 Oct. 2007, leg. D. Karasiński 970 (Herb. D.K., KRAM F-56623); Kaszubski Landscape Park, Kurze Grzędy Reserve, on bark of Picea abies stump, 4 Dec. 2008, leg. D. Karasiński 2703 (Herb. D.K.); Kaszubski Landscape Park, Bącz, ca. $2.5 \mathrm{~km}$ SW of Mirachowo, managed mixed forest, on very rotted wood of Pinus sylvestris L. stump, 5 Dec. 2008, leg. D. Karasiński 2725 (Herb. D.K., KRAM F-56624); the same locality, substrate and date, leg. D. Karasiński 2744 (Herb. D.K.).

DistRIBUTION AND ECOLOGY: Lawrynomyces capitatus is an European taxon, reported from Sweden (Eriksson, Ryvarden 1975), Norway (Ryvarden et al. 2003), Finland (Kotiranta et al. 2009), Denmark (Hjortstam 1984), Germany (Ostrow, Dämmrich 2010), Switzerland (Breitenbach, Kränzlin 1986), Belgium, Croatia, Czech Republic, Estonia and France (Bernicchia, Gorjón 2010). It was reported from southern Poland (Wojewoda 2003) and from three new localities from northern Poland reported here. In addition to Europe, it was reported from Turkey in Asia Minor (Sesli, Denchev 2011). It is not known from the tropics, subtropics and the southern hemisphere (Hjortstam, Ryvarden 2007).

Lawrynomyces capitatus is associated with much decayed wood of conifers. In one case, a basidiome was collected from the bark of Picea abies stump in an early stage of decomposition.

\section{DISCUSSION}

The main morphological features of the genus Lawrynomyces are a monomitic hyphal system with clampless hyphae, suburniform and more or less pedunculate basidia with prominent sterigmata, and smooth, hyaline, inamyloid, acyanophilous, broadly ellipsoid basidiospores with slightly thickened walls. The basidia of Lawrynomyces are similar to those observed in species of Hyphoderma s.str. but are typically pedunculate, i.e. with a stalk. The phylogenetic position of Hyphoderma capitatum supports recognition of separate genus for this species.

The other species that may be a member of the genus Lawrynomyces is Hyphoderma orphanellum (Bourdot \& Galzin) Donk. Although H. orphanellum has basidia and cystidia of similar shape to Lawrynomyces, it has clamped hyphae, thin-walled spores, encrusted hyphidia, and a dense, agglutinated subiculum (Eriksson, Ryvarden 1975; Bernicchia, Gorjón 2010). In some molecular phylogenetic studies $H$. orphanellum is shown to be in the same, well supported monophyletic clade with Lawrynomyces capitatus (Larsson 2007a; Miettinen, Larsson 2011; Nakasone, Burdsall 2012). However, these studies used the same ITS and/ or LSU sequence of $H$. orphanellum derived from NH 12208 from Russia. Another 
sequence of $H$. orphanellum was included in the phylogenetic tree presented by Tellería et al. (2012). In this study, H. orphanellum was placed in the Peniophorella clade. Because of these conflicting results, I accept a narrow concept of the genus which so far is monotypic.

Acknowledgements. Marcin Piątek, Anna Ronikier (Kraków, Poland) and an anonymous reviewer are thanked for valuable comments and suggestions to improve this manuscript. This work was partly supported by the Polish Ministry of Science and Higher Education (grant no. N N304 079535 for the years 2008-2011) and statutory funds of W. Szafer Institute of Botany PAS.

\section{REFERENCES}

Bernicchia A., Gorjón S.P. 2010. Corticiaceae s.l. Fungi Europaei 12: 1-1008.

Breitenbach J., Kränzlin F. 1986 Fungi of Switzerland 2. Heterobasidiomycetes (jelly fungi), Aphyllophorales (non-gilled fungi), Gasteromycetes (puffballs). Verlag Mykologia, Lucerne.

Eriksson J., Ryvarden L. 1975. The Corticiaceae of North Europe 3: 284-546.

Hallenberg N. 1990. Ultrastructure of stephanocysts and basidiospores in Hyphoderma praetermissum. Mycol. Res. 94: 1090-1095. http://dx.doi.org/10.1016\%2FS0953-7562\%2809\%2981339-7

Hjortstam K. 1984. Corticiaceous fungi of northern Europe - check-list of the species in the Nordic countries. Windahlia 14: 1-30.

Hjortstam K., Ryvarden L. 2007. Checklist of corticioid fungi (Basidiomycotina) from the tropics, subtropics and the southern hemisphere. Synopsis Fungorum 22: 27-146.

Karasiński D. 2010. Polish resupinate Russulales: the genus Vararia. Acta Mycol. 45 (1): 45-56.

Kotiranta H., Saarenokasa R., Kytövuori I. 2009. Aphyllophoroid fungi of Finland. A checklist with ecology, distribution and threat categories. Norrlinia 19: 1-223.

Larsson K.-H. 2007a. Molecular phylogeny of Hyphoderma and the reinstatement of Peniophorella. Mycol. Res. 111: 186-195. http://dx.doi.org/10.1016\%2Fj.mycres.2006.10.002

Larsson K.-H. 2007b. Re-thinking the classification of corticioid fungi. Mycol. Res. 111: 1040-1063. http:// dx.doi.org/10.1016\%2Fj.mycres.2007.08.001

Larsson K.-H., Larsson E., Köljalg U. 2004. High phylogenetic diversity among corticioid homobasidiomycetes. Mycol Res. 108: 983-1002. http://dx.doi.org/10.1017\%2FS0953756204000851

Larsson K.-H., Parmasto E., Fischer M., Langer E., Nakasone K.K., Redhead S.A. 2006. Hymenochaetales: a molecular phylogeny for the hymenochaetoid clade. Mycologia 98: 926-936. http://dx.doi.org/10.3 $852 \% 2$ Fmycologia.98.6.926

Miettinen O., Larsson K.-H. 2011. Sidera, a new genus in Hymenochaetales with poroid and hydnoid species. Mycol. Progress 10: 131-141.

Miettinen O., Rajchenberg M. 2012. Obba and Sebipora, new polypore genera related to Cinereomyces and Gelatoporia (Polyporales, Basidiomycota). Mycol. Progress 11: 131-147.

Nakasone K.K., Burdsall H.H. 2012. Tsugacorticium kenaicum (Hymenochaetales, Basidiomycota), a new corticioid genus and species from Alaska. North American Fungi 7 (1): 1-9.

Ostrow H., Dämmrich F. 2010. Corticioid Basidiomycetes in Germany. Z. Mycol. 76(2): 177-210.

Ryvarden L., Stokland J., Larsson K.-H. 2003. A critical checklist of corticioid and poroid fungi of Norway. Synopsis Fungorum 17: 1-79.

Sesli E., Denchev C.M. 2008. Checklists of the myxomycetes, larger ascomycetes, and larger basidiomycetes in Turkey. Mycotaxon 106: 65-67 + online version [2013-01]: 1-145 http://www.mycotaxon. com/resources/checklists/sesli-v106-checklist.pdf

Tellería M.T., Dueñas M., Beltrán-Tejera E., Rodríguez-Armas J.L., Martín M. 2012. A new species of Hyphoderma (Meruliaceae, Polyporales) and its discrimination from closely related taxa. Mycologia 104 (5): 1121-1132.

Tzean S.S., Liou J.Y. 1993. Nematophagous resupinate basidiomycetous fungi. Phytopathology 83: 1015-1020.

Wojewoda W. 2003. Checklist of Polish larger Basidiomycetes. (In:) Z. Mirek (ed.). Biodiversity of Poland. 7. W. Szafer Institute of Botany, Polish Academy of Sciences, Kraków, 812 pp. 
Lawrynomyces - nowy rodzaj grzybów kortycjoidalnych w rzędzie Hymenochaetales

\section{Streszczenie}

W pracy opisano nowy rodzaj Lawrynomyces Karasiński gen. nov., dla Hyphoderma capitatum. Typ rodzaju jest gatunkiem notowanym głównie z Europy, stwierdzonym także w Azji Mniejszej i nieznanym z innych kontynentów. Występuje na mocno rozłożonym drewnie iglastym, głównie Picea abies, rzadziej Pinus sylvestris, w lasach mieszanych i iglastych, zarówno naturalnych jak i sztucznego pochodzenia, a owocniki wytwarza zazwyczaj późną jesienią. Nowy rodzaj należy do tzw. „kladu Rickenella” w rzędzie Hymenochaetales. Cechami charakterystycznymi dla Lawrynomyces są rozpostarte, miękko błonkowate i białawe do szaro kremowych owocniki, bardzo cienkie $(60-150 \mu \mathrm{m})$, tworzące na drewnie nieregularne w zarysie powłoczki (Fig. 2 i 3), gładki hymenofor, monomityczny system strzępkowy ze strzępkami generatywnymi bez sprzążek, obecność cystyd tramalnych i hymenialnych oraz hyfid, podstawki niewyraźnie urnokształtne do niemal cylindrycznych z trzoneczkowatą podstawą oraz zarodniki szeroko elipsoidalne do prawie kulistych z grubiejącymi ścianami (Fig. 1), nie wykazujące reakcji w odczynniku Melzera i roztworze błękitu bawełnianego. W blisko spokrewnionym z Lawrynomyces rodzaju Peniophorella, podstawki mają kształt maczugowaty, zarodniki są cienkościenne, a należące tu gatunki często wytwarzają na strzępkach kontekstu charakterystyczne struktury - echinocysty i sferocysty, nieobecne u Lawrynomyces. Umieszczenie Hyphoderma capitatum w odrębnym rodzaju ma uzasadnienie w publikowanych danych molekularnych. 